\title{
Analysis of Female Masculinity During Wartime in The Night Watch From the Perspective of Gender Performativity*
}

\author{
Lin $\mathrm{Wu}$ \\ School of Foreign Languages, Central South University, Changsha, China \\ Chenyu Bai \\ School of Foreign Languages, Central South University, Changsha, China
}

\begin{abstract}
The novel The Night Watch (2006) by Sarah Waters, a contemporary British novelist, tells the story of four women whose fortunes were intertwined before and after World War II. By Judith Butler's theory of gender performativity, this paper analyzes the wartime female images in the novel. Women' $s$ wartime drag subverts the binary opposition of people's presupposed notion about sex and women' s occupation of men' job that breaks the fictitious perception of gender opposition; the lesbian love affairs challenge the compulsory heterosexuality. Through the interpretations of the feminist thoughts conveyed by Waters in The Night Watch and Butler's theory of gender performativity, it can be discovered that the nature of gender identity is actually fictional and can be constructed, reflecting the appeal for gender equality.
\end{abstract}

Index Terms - gender performativity, Judith Butler, feminism, war, The Night Watch

\section{INTRODUCTION}

Sarah Waters (1966--) is a contemporary British novelist who is best known for her novels set in Victorian society and featuring lesbian protagonists, such as Tipping the Velvet (1998) and Fingersmith (2006).

The Night Watch (2006) is a dark, historical fiction novel by Waters, which has been nominated in the short lists of Man Booker Prize for Fiction and Orange Prize for Fiction in 2006. It tells the story backward through third-person narrative, taking place in 1940s London during and after World War II. The storyline follows the fragmented lives and the strange interconnections between four characters. Especially the female characters in this novel subvert the traditional gender roles during wartime by being writers, workers and ambulance drivers and cutting short hair, wearing trousers and smoking cigarettes, all of whom present masculinity within female bodies that challenges the traditional gender identity.

Judith Butler's gender performativity holds that stable categories of binary oppositions such as man Iwoman, male $\backslash$ female, can be deconstructed by revealing how "they are discursively constructed within a heterosexual matrix of power" (Judith Butler, 1990, p. 30) In The Night Watch, women at wartime behave manly, especially the main character Kay who is always mistaken as a "young man", exemplifying Butler's notion that gender is constructed and performed. Meanwhile, the hostile and unkind attitude toward Kay on account of her masculine physical appearance indicates the restraints and prejudice that heterosexual society imposed on butches. In the novel, Waters frequently describes her female characters as manly and heroic who "carried stretchers" in the wartime (Sarah Waters, 2006, p. 55) to dash the traditional images of female-fragile and maiden-like. Such binary oppositions of gender are also challenged and criticized by Judith Butler. By applying Butler's theory of gender performativity, this paper focuses on the core concepts of drag, gender identity, and compulsory heterosexuality, probing into the relationship between war and women's life, and interpreting the female masculinity in The Night Watch to analyze its impact on British society at that time.

\section{DRAG: Subverting the BinaRy OPPOSITION OF BIOLOGICAL GendeR}

Beauvoir put forward in Second Sex (1973) that One is not born a woman, but rather becomes one" (Simone De Beauvoir, 1973, p. 301), admitting that the biological sex category of human beings, which is an established fact, but his/her gender identity is open and can be changed. Butler questioned this view, thinking that both sex and gender are constructed and are the result of a heterosexual mechanism. In The Night Watch, Waters used "drag" --woman wearing man's clothing to reveal the fiction of the dual opposition of masculinity and femininity, exposing the oppression of women caused by gender norms related to femininity, and criticizing the hegemony of masculine discourse on masculinity. And such arrangement in this novel subverts the naturalized sexual differences.

\footnotetext{
${ }^{*}$ Notes: This article is sponsored by the Social Science Foundation Project of Hunan Province of China. The number of the project is 17 YBA416.
} 
The female characters in The Night Watch are often wear men's clothing during the Second World War. In the first place, this kind of cross- dressing is a convenient move. Because in terms of clothes styles, men's clothing is characterized by looseness, comfort and practicality, such as jackets, overalls, etc. Compared with men's wear, women's styles are more diversified, and their designs are more refined, and are mostly characterized by aesthetics, such as dresses and skirts. In terms of materials, there are also differences between men's and women's clothing. Men's clothing is mostly made of coarse cloth and denim, while materials of women's clothing also include cotton, linen, silk and other materials. In 1940s, the war not only destroyed the daily production of the city, but also damaged the transportation system, which made the transportation of materials extremely difficult. The raw materials for women's clothing are more difficult to produce and transport than men's clothing. In this case, it was a common phenomenon for women to change into men's clothing. At the same time, the war forced men to the battlefield, and women have to participate in some daily household affairs that are once performed by men, such as repairing household appliances and water pipes. Out of this consideration, women would also dress men's clothing. In the novel, when Helen was injured in a big explosion and was crushed under a collapsed house, the doctor who came to examine her body "was a brisk, handsome woman of forty-five or so. She was dressed in dungarees and a turban” (Sarah Waters, 2006, p. 380). Waters's detailed description of the female doctor here juxtaposes the two seemingly unmatched images of "handsome woman" and "dungarees" to portray a tough and masculine female image. This image of a tough woman shows that women have the same presupposed masculinity such as courage and calmness in the face of difficulties and crises.

In fact, drag is an ancient cultural phenomenon in most theaters of the world with a long history of men and women swapping costumes and reversing roles, reflecting an expression of identity. Butler clarifies the instability and constructivity of gender identity through the cultural phenomenon of drag. Through drag, subject can imitate the gender that it wants to be. Butler argues that, drag "implicitly reveals the imitative structure of gender itself---as well as its contingency" (Judith Butler, 1990, p. 186). In Butler's context, drag mainly refers to homosexuals distinguishing active and passive roles with different gender clothing styles. For example, in a homosexual relationship, a physiological male who is internally identified with a female role will use lipstick, stockings, wrap skirts, etc. to dress himself up as a female to reflect the difference between his physical appearance and his inner identity. The concept of drag shows that "the inner truth of gender is a fabrication", while "true gender is a fantasy instituted and inscribed on the surface of bodies" (Judith Butler, 1990, p. 186). The heroine of the novel, Kay, is often mistaken for a man because of her neat short hair and men's clothing. "She is often called "young man" or even "son" by older women. As an openly lesbian, Kay performs the male sex by wearing men' s clothing and cutting her hair short, in order to openly express her homosexuality and challenge the traditional sex distinction in the heterosexual system. Her appearance of "masculinity" subverts the traditional image of women ---dressed as a lady, with gentle demeanor. According to Butler's notion, Kay's drag reflects the instability of a fixed gender identity presupposed by heterosexual ideology. Kay is biologically female, and she exhibits masculinity, which subverts the presupposition that men should have masculinity and women should have the ideology of femininity, breaking the biological gender opposition. In fact, the use of drag to change or conceal the gender identity standardized by the body blurs the boundary between the anatomical body of the dresser and the gender being performed. The construction of gender identity is a parody of identity politics and the political strategy of feminism to denaturalize gender. This strategy is based on the idea that "the inner truth of gender is a fabrication" (Judith Butler, 1990, p. 186), subverting the gender oppositions of humans in heterosexual society to prove the imitability and contingency of the nature of gender.

At the same time, Kay's “drag” is also a power appeal, in order to obtain equal rights and treatment with men. During the war, Kay worked as an ambulance driver for the emergency rescue team. She often shuttled through the hard-hit streets of London, constantly passing by with death. However, due to Kay's female identity, even if she encounters an accident, her lesbian partner cannot receive any financial compensation. "It's not even as if Helen would get any kind of pension if I was killed" (Sarah Waters, 2006, p. 197). During World War II, if a woman's husband died on the front lines, she would receive financial compensation from the government as comfort. Helen and Kay are same-sex couples and such kind of relationship was not recognized by the law in the United Kingdom at the time. Therefore, Helen could not receive government pensions as Kay's family, which was an extremely painful thing for Kay. She tried her best to show her masculinity by cutting her hair short and wearing men's clothing, reflecting her desire for equal rights.

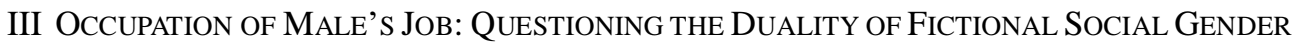

Kay, Mickey, and Julia in The Night Watch all took on tasks usually done by men during World War II. This is undoubtedly an externalized embodiment of masculinity in women, questioning the duality of social gender.

Although the cruel and merciless war has caused huge losses to the entire society, it also provided more job opportunities for women in the home front. Since World War II was a modern war, every citizen of the countries participating in the war was closely related to it. In this war, when men went to the front, women were important members of society. They were active in all walks of life and contributed much to the war. From the outbreak of World War II to 1943, the number of women workers from all walks of life who directly or indirectly served the war increased rapidly. As of 1943, 1.5 million women had entered the officially designated "core" industry, that is, industries related to munitions. Female workers in the engineering industry rose from 97,000 in 1939 to 602,000 in 1943, and the proportion of female workers rose from $10 \%$ to $34 \%$. Similar changes have occurred in the metal industry, chemical industry, 
automobile manufacturing, transportation, petroleum, water supply, electricity, and shipbuilding. Women in these industries rose from $14 \%$ in 1939 to $33 \%$. Women in business and government are also expanding (G.M. Beck, 1951). Academic research on women's direct or indirect participation in the war during World War II also shows that women took on "male-dominated" jobs during World War II, and strongly supported working on the front and rear of the war.

Waters subtly incorporated these historical facts into her novels, showing the strong and brave masculinity of female characters, breaking the social stereotype that women cannot hold certain positions. As the ambulance driver of the rescue station during the war, Kay was alert and sober when handling the wounded during rescue work. On the way to the bombed Dolphin Square, although "The van was an old commercial one that had been converted at the start of the war; she had to double-declutch with every gear change-a rather tiresome business. But she knew the vehicle and all its quirks, and went smoothly, confidently" (Sarah Waters, 2006, p. 149). In traditional views, the work of drivers should be undertaken by men, but Kay's proficient driving skills actually dash the traditional gender concepts. At this time, her social gender as a woman is also disintegrated. Because gender is "an identity tenuously constituted in time, instituted in an exterior space through a stylized repetition of acts" (Judith Butler, 1990, p. 140). Kay was engaged in work that was originally occupied by male, showing the masculinity of women, and deconstructing the gender definition in the heterosexual discourse system. During an outing mission, Kay and her colleague Mickey are rescuing the bloody wounded, while the air defense administrator of that street "looked Kay and Mickey, over 'Not much of a job for women" (Sarah Waters, 2006, p. 338) Because in the view of air defense administrator, women were mostly gentle and fragile, unable to cope with cruel wars. The reason is that in the patriarchal culture, the unjust gender hierarchy has produced fictitious female images and presupposed femininity. In this gender essentialist system, men are considered strong, brave, active, and rational, and therefore occupy a dominant position in society; while women are considered weak, timid, passive, and emotional. This stereotyped image requires women to maintain femininity, to be good wives and mothers, to become "angel in the house" (Coventry Patmore, 1863) and to be in a dominated position in society.

Kay is the most heroic character in the novel, exemplifying female masculinity to a large extent. With her determination and courage, she "attacked" the patriarchal society and "killed" the "angel in the house", enabling the female voice to be heard. Kay and Mickey were bombarded by incendiary bombs when they were on the mission, and the incendiary bombs quickly turned the entire neighborhood into a sea of flames. Facing the horrible street, although they must follow the route according to the regulations of the ambulance station, Kay "made a decision, and stopped the van, as close as she dared get to the spluttering rocket. 'I'm not going to leave this street to catch fire,' she said, opening her door and jumping out" (Sarah Waters, 2006, p. 157). The words “opening”, and "jumping” show Kay's psychological state. Faced with wanton burning bombs, it is natural to be afraid. However, Kay overcame the fear in her heart, disregarding the rules and regulations and her own safety, and resolutely chose to rescue the masses in the flames, reflecting her spirit of self-sacrifice. After completing the rescue work, Kay received harsh accusations from the rescue station chief for parking in violation of regulations, but she always insisted on her decision, "You'd like me to leave a street to burn and bring more bombs? We'd have lots of jobs, then" (Sarah Waters, 2006, p. 160). Kay's heroism is obvious. She puts the safety of the masses above self-safety, and fiercely resisted the reproach of the stationmaster, proving that women can also remain brave and rational in the face of disasters, and questioned the fictional images and predictions of women in a patriarchal society.

Julia, another female character in the novel, also worked in a harsh environment that was more suitable for men during the war. She was an assistant to her father, an architect, and was responsible for surveying the bombed house. Julia's working environment was extremely intolerable. She traveled through London's "tall and gloomy, dilapidated" houses all day long. These houses have become "deserted" under the impact of gunfire. In the second meeting between Julia and Helen, Julia invited Helen to see her work. After they entered this empty house, Helen found that the house was "dusty, and heavily marked by flying glass and fallen plaster" (Sarah Waters, 2006, p. 205), "She went to a set of high double doors and carefully pulled them ajar. The room beyond was just as wretched as this one-its window smashed, its velvet curtains marked with rain, spots on the floor where birds had dirtied, soot and cinders blasted from the hearth" (Sarah Waters, 2006, p. 206). Images such as "soot", “cinders", illustrate the destruction of London's urban architecture caused by the war, and also emphasize the uniqueness of Julia's work. As Julia herself said, "we are recording ghosts" (Sarah Waters, 2006, p. 239). Julia followed her father all day long in the crumbling house, doing dangerous and hard work, contrary to the traditional "angel in the house" female image. This job is just as Julia's father said, "Queer sort of job, isn't it? All dust" (Sarah Waters, 2006, p. 214). However, Julia enjoyed herself in this "queer" job. Although she would be smashed and bruised by dilapidated buildings from time to time, she thought this job is suitable for her, "because it's so solitary, so silent" (Sarah Waters, 2006, p. 206). Julia took on such a hard job and enjoyed it. Her masculinity was reflected in this job, which deconstructed the duality of gender. In fact, gender should be regarded as a fluid variant that changes with time and occasions, the gender identity of the subject is the result of "institutions, practices, discourses" (Judith Butler, 1990, p. xxxi) not their causes. And Julia's gender at this time has also become fluid and unstable due to her work.

Not only Kay and her rescue team colleagues, but also Julia, these female figures have served the "male jobs" in the

\footnotetext{
${ }^{1}$ Following the publication of Patmore's poem, the term "angel in the house" came to be used in reference to women who embodied the Victorian feminine ideal: a wife and mother who was selflessly devoted to her children and submissive to her husband. The term then evolved into a more derogatory assessment of antiquated roles with critiques from popular feminist writers like Virginia Woolf.
} 
patriarchal society during the war, and did their jobs brilliantly, revealing the fiction of social gender. At this time, "angel in the house" is dead, and replaced by new women who have stepped out of the house to take on important tasks. Waters combines the historical facts of World War II with the characterization in her novel, conveying her own feminist thoughts, and showing her questioning of the traditional definition of gender.

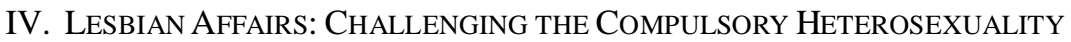

The emotional entanglements of Kay, Julia, and Helen run through the entire novel. The romantic and complicated relationship between them not only reflects the masculinity of women, but also challenges the compulsory heterosexuality. Because in the heterosexual matrix, only heterosexual sexual desire and sexual practice are legal, but in Butler's view, the gender subject based on heterosexuality is unstable because there are diverse forms of sexual desire and sexual practice, such as bisexuality and homosexuality. The lesbian relationship in the novel is the diversified manifestation of sexual desire, challenging the "system of compulsory heterosexuality that clearly operates through a system of compulsory sexual reproduction" (Judith Butler, 1990, p. 150).

The emergence of homosexuality is inseparable from the background of war at the time. War broke the conventions of traditional society and produced a kind of "queer time/space". American feminist Halberstam put forward the concept of "queer time" in the book In A Queer Time and Place: Transgender Bodies, Subcultural Lives (2004). She believes that time is usually "hetero-normative", in other words, time is governed by "normal" routines, and these routines are composed of traditional gender, sexual orientation and family structure. But when society and culture encounter crises, "alternative modalities of time and place that challenge the hetero-normative arrangements of temporality and material relations emerge" (Judith Halberstam, 2004, p. 2) Time and space become "queer" because it develops "in opposition to the institutions of family, heterosexuality, and reproduction'(Judith Halberstam, 2004, p. 1). The war prompted the original management norms of the society to be changed, breaking the conventions of traditional society. At this time, London can be regarded as a "queer" space, which catalyzed women's homosexual affection between themselves. The first encounter between Kay and Helen was almost "the hero rescued the beauty" style, showing Kay's calmness, wit and bravery. Kay found Helen in the ruins during a rescue operation after an air raid. Helen was still crushed in the ruins and was distressed. Kay patiently bandaged her wounds and chatted with her to relieve her anxiety. In Waters's writing, the brave and fearless Kay rescued the fragile and helpless Helen from the ruins, which is actually a parody and rewriting of the traditional story model of "the hero rescued the beauty" In classic Western fairy tales, whether it is "Snow White", "Little Red Riding Hood" or "Sleeping Beauty", the heroine always suffers from various disasters and sufferings, such as being abused by a stepmother, cursed by a witch, or facing danger to life. At the end of the story, there is often a brave and handsome male figure to save the situation. This male character will use his bravery and wisdom to successfully rescue the heroine in trouble and live happily with her. Waters transplanted this traditional story model into the World War II novel The Night Watch, creating a romantic encounter between Kay and Helen, but she cleverly changed the gender identity of the two protagonists of the story to female, giving Kay a kind of heroic and masculine temperament of male, breaking the traditional setting of "the male hero saving a beauty". Just like the ending of a romantic fairy tale, both Kay and Helen developed a kind secret affection for each other, in Kay's own feelings to describe, "she does not want to leave her, after all; gazing at her in a sort of wonder; unable to believe that something so fresh and so unmarked could have emerged from so much chaos" (Sarah Waters, 2006, p. 383). In the relationship between Kay and Helen, Kay represents the male side of the heterosexual love model. Kay's ex-girlfriend Julia once said to Helen, Kay "She wants a wife-someone good, I mean; someone kind, untarnished. Someone to keep things in order for her, hold things in place" (Sarah Waters, 2006, p. 324). The term "wife" means "a man's official spouse" in a traditional sense. As a woman, Kay "wants a wife" undoubtedly challenges the gender norms of heterosexual society. Butler believes that homosexuality to heterosexuality is "not as copy is to original, but, rather, as copy is to copy" (Judith Butler, 1990, p. 43). Kay and Helen's lesbian relationship is obviously very different from "heterosexual production and reproduction of desire" (Judith Butler, 1990, p. 123), and in this lesbian relationship, the body becomes a flexible and fluid field. The rigid opposition between gender, gender identity and gender performance no longer exist.

The war not only provided an opportunity for Kay and Helen's romantic encounter, but also contributed to the unexpected love affair between Julia and Helen. Under the bombardment of artillery, London became devastated and dilapidated. In order to deal with enemy air strikes, city management regulations have also changed. London citizens must accept extraordinary wartime management measures. The authorities required all urban residents to move to air raid shelters when the air defense alarm sounds and shut down all power supply systems to protect the city from enemy bombing. From September 1, 1939, in order to avoid becoming a bomb target of German aircraft, London implemented light control, and London at night fell into darkness for 5 years. In the novel, Julia and Helen walk through the streets of London late at night like "urban wanderers". While Julia was walking with Helen, the two were attacked by air strikes. At this time, Helen had realized that she had a secret affection for Julia. At the same time, she fell into deep entanglement and pain because she already lived together with Kay. Just as Helen was struggling and depressed, this sudden airstrike became a catalyst between her and Julia, and Helen's affection for Julia was infinitely spreading. Meanwhile the dark city also created opportunities for the two to open their hearts. Although for Helen, leaving a place she was familiar with during the light control period was always disturbing because "Anyone could come at us out of the dark." (Sarah Waters, 2006, p. 277), Julia thought this was a good thing, "But if we can't see them, they can't see us. 
Besides, they'd probably take us for a boy and his girl" (Sarah Waters, 2006, p. 277). Homosexuals who were originally not to be accommodated by the society had temporal freedom under the cover of darkness. Because the gender norms under the heterosexual matrix are defined by society, and gender identity is strictly regulated by heterosexual culture, and any gender identity that violates this gender norm is internalized as taboo. And in a heterosexual society, "gender is a performance with clearly punitive consequences" (Judith Butler, 1990, p. 190), and society often punishes those who "wrongly" perform their own gender. The homosexuality between Julia and Helen is obviously a kind of "wrong" gender performance, which cannot be accepted by the traditional heterosexual society. They will be hindered and criticized by society and their family. As in the third part of the novel, by 1947, however, with peace declared, cultural attitudes to woman's role in society and feminine dress conventions have undergone a dramatic shift" (Paulina Palmer, 2008 , p. 81), requiring women to return to the pre-war social division of labor and family role. Facing such a social situation, Julia as a writer had to hide her sexual orientation from the public. As Helen said, "Now that Julia's books were doing so well, they had to be more careful than ever (Sarah Waters, 2006, p. 48). However, in 1944, the war disrupted the normal operation of the city, affected people's daily life, and gave homosexuals temporal freedom. They wandered in the city under the control of the lights and became the "invisible" (Sarah Waters, 2006, p. 286) in the city, and they could be like heterosexuals without covering their sexual orientation.

London under the control of the lights during World War II provided a refuge for the two homosexual desires, allowing lesbians to freely perform their gender and sexual orientation, proving the diverse forms of erotic desire and sexual practice, and challenging the traditional hegemonic society of heterosexuality.

\section{CONCLUSION}

Regarding the attitude of feminism, Waters once stated that "feminism is part of a wider struggle against all inequalities' only to then retort" (Sarah Waters, 2008). The anti-traditional female role she portrayed in The Night Watch under the background of World War II is a questioning of the gender concept of patriarchy, and is intended to convey the idea of gender equality. In the novel, the women in the novel perform the traditional concept of masculinity by drag, undertaking male jobs, and having lesbian affairs during wartime, subverting the distinction between male and female sex temperament and breaking the traditional gender boundaries. Using Butler's theory of gender performativity to interpret The Night Watch, explore the background of the times and women's gender performativity, World War II provided the women in the novel with the possibility of performing male gender. The identity of the performed gender is actually a subversion and resistance to the heterosexual gender hierarchy, a demand for the reconstruction of the gender subject, and a manifesto for women to strive for individuality and independence.

\section{REFERENCES}

[1] Beauvoir, De Simone. (1973). The Second Sex, trans. E. M. Parshley. New York: Vintage Press.

[2] Beck, G.M. (1951). Survey of British Employment and Unemployment1927-1945, Oxford: Oxford University Institute of Statistics.

[3] Butler, Judith. (1990). Gender Trouble: Feminism And The Subversion Of Identity. New York: Routledge, Chapman \& Hall, Inc.

[4] Halberstam, Judith. (2005). In a Queer Time and Place. New York: New York University Press.

[5] Palmer, Paulina. (2008). 'She began to show me the words she had written, one by one': Lesbian Reading and Writing Practices in the Fiction of Sarah Waters, Women: a cultural review 19.1, 69-86.

[6] Patmore, Coventry Kersey Dighton. (1863). The Angel in the House, Part I. London: Macmillan \& Co.

[7] Waters, Sarah. (17/12/2008). The Sawcett https://www.flickr.com/photos/fawcettsociety/3114961665/.(accessed26/12/2020)

[8] Waters, Sarah. (2006). The Night Watch. London: Virago.

Lin Wu was born in Hunan Province, People's Republic of China in 1973.She is currently an associated professor in School of Foreign Languages of Central South University in China. She received a Doctor Degree specialized in English literature. Her research interests are Eco-feminism and contemporary American literature.

Chenyu Bai was born in Henan Province, People's Republic of China in 1997. She is currently a postgraduate student in School of Foreign Languages of Central South University in China. Her research interests are gender, feminism and British novels. 